\title{
Risiko Terjadinya Dekubitus Berdasarkan Tingkat Ketergantungan Pasien di Ruang Perawatan Neurologi
}

\author{
Okatiranti $^{1}$, Ria Eviyanti Sitorus ${ }^{2}$, Dini Tsuawabeh ${ }^{1}$ \\ ${ }^{1}$ Fakultas Ilmu Keperawatan Universitas BSI Bandung, ${ }^{2}$ RSUP Dr. Hasan Sadikin \\ E-mail: okatiranti@yahoo.com
}

\begin{abstract}
Abstrak
Dekubitus merupakan masalah akut yang sering terjadi pada situasi perawatan pemulihan. Gangguan ini terjadi pada individu yang mengalami tirah baring lama serta mengalami gangguan tingkat kesadaran. Ketika dekubitus terjadi maka lama perawatan dan biaya perawatan rumah sakit akan meningkat. Hasil penelitian di beberapa Rumah Sakit pemerintah di Indonesia kejadian dekubitus pada pasien tirah baring 15,8\% sampai 38,18\%. Tujuan penelitian untuk mengidentifikasi gambaran risiko terjadinya dekubitus berdasarkan tingkat ketergantungan pasien minimal care, partial care, dan total care. Metode penelitian yang digunakan adalah deskriptif. Sampel berjumlah 88 orang. Instrumen penelitian menggunakan lembar observasi menurut Teori Orem: Self Care untuk mengkaji tingkat ketergantungan pasien dan Skala Braden untuk prediksi luka tekan. Hasil penelitian gambaran risiko terjadinya dekubitus berdasarkan tingkat ketergantungan pasien minimal care sebesar 88,24\% atau hampir seluruhnya tidak memiliki risiko untuk terjadinya dekubitus, partial care sebesar $45,95 \%$ atau hampir setengahnya yang berisiko terjadinya dekubitus dan total care sebesar $44,12 \%$ atau hampir setengahnya yang memiliki risiko tinggi terjadinya dekubitus. Hasil Penelitian dapat dijadikan sebagai pertimbangan untuk membuat Standar Operasional Prosedur (SOP) pencegahan dekubitus khususnya pada pasien yang berisiko sampai dengan total care. Sehingga perawat khususnya perawat klinik dapat mengantisipasi risiko terjadinya dekubitus sesuai dengan SOP yang sudah ada.
\end{abstract}

Kata kunci: Dekubitus, orem, skala Braden, tingkat ketergantungan pasien.

\section{The Risk of Decubitus Incidence Based on Patients' Dependency Level in Neurological Ward}

\begin{abstract}
The incidence of decubitus is one of the most acute problems in recovery phase. This problem occurred to individual who has long-term bed rest period and has alteration of consciousness. Previous studies in public hospitals in Indonesia showed that the incidences of decubitus among the bed-rest patients are $15.8 \%$ to $38.1 \%$. The aim of this study is to identify the risk of incidence of decubitus based on patients' dependency level: minimal care, partial care, and total care. This study used descriptive quantitative design with 88 patients as the research samples. Observational check-list which is developed from Orem's theory is used as the research instrument. Self-care is used to assess level of patients' dependency and Braden Scale is used to predict the decubitus. The result shows that most of the patients at minimal care level (88.24\%) do not have the risk of decubitus wound; almost half of patients at partial care level (45.95) have the risk of decubitus; while almost half of patients at total care level (44.12\%) have the high risk of developing decubitus. This result can be considered to develop Standard Operational Procedure (SOP) of decubitus prevention, particularly for patients with total care who are at risk of developing decubitus. Therefore, nurses in the ward can prevent the incidence of decubitus among patients.
\end{abstract}

Key words: Braden scale, decubitus, orem, patients' dependency level. 
Okatiranti: Risiko Terjadinya Dekubitus berdasarkan Tingkat Ketergantungan Pasien

\section{Pendahuluan}

Dekubitus merupakan masalah akut yang terus-menerus dari situasi perawatan pemulihan. Dekubitus adalah nekrosis jaringan lokal yang cenderung terjadi ketika jaringan lunak tertekan di antara tonjolan tulang dengan permukaan eksternal dalam jangka waktu lama (Potter \& Perry, 2005).

Penelitian di Indonesia menyebutkan bahwa dari 72 orang pasien tirah baring yang dirawat di RSUP Dr. Wahidin Sudirohusodo Makasar, sebanyak 12 orang (15,8\%) mengalami dekubitus. Setyajati (2001) juga melakukan penelitian yang menghitung angka kejadian dekubitus pada pasien tirah baring di RS Murwadi Surakarta, pada bulan Oktober 2002 angka kejadian dekubitus sebanyak $38,18 \%$. Penelitian tentang angka kejadian dekubitus juga menyebutkan di ruang A1, B1, C1, D1 dan di ruang B3 IRNA I RSUP Dr. Sardjito pada bulan Oktober 2001, didapatkan hasil dari 40 pasien tirah baring, angka insidensi mencapai 40\%. Berdasarkan data rekam medis, ruang Kemuning lantai 5 dalam satu tahun terakhir didapatkan 87 pasien yang mengalami dekubitus. Pada bulan Februari 2013, berdasarkan hasil pengkajian dengan perawat ruangan neurologi didapatkan $6,25 \%$ pasien yang mengalami dekubitus dari 80 pasien yang dirawat.

Dekubitus dapat terjadi pada individu yang mengalami penurunan kesadaran. Dekubitus meningkatkan lama perawatan dan biaya perawatan rumah sakit (Potter \& Perry, 2005). Tingkat ketergantungan mobilitas pasien merupakan faktor yang langsung memengaruhi risiko terjadinya luka (Ignatavicius \& Linda, 2002). Pasien yang dirawat inap di instalasi rawat inap mempunyai tingkat ketergantungan yang berbeda. Menurut teori Orem dalam Taylor dan Renpenning (2011), klasifikasi tingkat ketergantungan pasien dibagi menjadi tiga, yaitu: minimal care/self care, partial care dan total care. Pengkajian awal terhadap integritas kulit perlu dilakukan oleh perawat, karena dengan perawatan yang tepat dan pencegahan yang memadai, baik ketika dirawat atau saat keluar dari rumah sakit, risiko perkembangan ulkus dekubitus mungkin menurun (Bansal \& Cheryl, 2005).

Pada penelitian ini, pengkajian risiko terjadinya dekubitus menggunakan kriteria skala Braden. Skala Braden terdiri dari 6 item yang mewakili faktor risiko untuk pengembangan ulkus tekanan, yaitu persepsi sensori, kelembapan, aktivitas, mobilitas, nutrisi, dan gesekan (Vanderwee, Grypdonck, Bacquer, \& Defloor, 2006). Berdasarkan hasil observasi langsung pada saat studi pendahuluan di RSUP Dr. Hasan Sadikin terlihat bahwa perawatan partial care dan total care masing-masing mempunyai risiko untuk terjadinya dekubitus. Oleh karena itu, antara ketergantungan pasien dengan risiko terjadinya dekubitus erat kaitannya. Sehingga, peneliti tertarik untuk meneliti di ruang perawatan penyakit neurologi, dengan melihat risiko terjadinya dekubitus berdasarkan tingkat ketergantungan pasien. Tujuan penelitian ini adalah untuk mengidentifikasi gambaran risiko terjadinya dekubitus berdasarkan tingkat ketergantungan pasien.

\section{Metode Penelitian}

Metode pada penelitian ini dilakukan dengan menggunakan metode penelitian deskriptif. Populasi dalam penelitian ini, yaitu seluruh pasien yang dirawat di ruang rawat inap gedung Kemuning lantai 5 neurologi RSHS Bandung. Teknik pengambilan sampel dalam penelitian ini menggunakan total sampling, sampel penelitian rata-rata seluruh pasien dalam waktu satu bulan berjumlah 88 pasien. Tempat penelitian di RSUP Dr. Hasan Sadikin Bandung, jalan Pasteur no. 38 Bandung 40161. Waktu penelitian pada tanggal 17 Juni 2013 hingga 11 Juli 2013.

Penelitian dengan menggunakan lembar observasi berdasarkan Teori Orem dalam Arikunto (2010) self care dan Skala Braden, penilaian terhadap tingkat ketergantungan pasien berdasarkan teori Orem dalam Taylor dan Renpenning (2011).

\section{Hasil Penelitian}

Karekteristik responden pada penelitian ini berdasarkan diagnosa, jenis kelamin pada pasien rawat inap lantai 5 Neurologi gedung Kemuning RSHS Bandung periode 17 Juni 
Okatiranti: Risiko Terjadinya Dekubitus berdasarkan Tingkat Ketergantungan Pasien

Tabel 1 Distribusi Persentase Karekteristik Responden Berdasarkan Diagnosa, dan Jenis Kelamin dan Usia pada Pasien Rawat Inap Lantai 5 Neurologi Gedung Kemuning di RSHS periode 17 Juni 2013 sampai dengan 7 Juli 2013

\begin{tabular}{lcccc}
\hline & \multicolumn{4}{c}{ Jenis Kelamin } \\
\cline { 2 - 5 } \multicolumn{1}{c}{ Diagnosa } & \multicolumn{2}{c}{ Pria Remaja } & \multicolumn{3}{c}{ Wanita } \\
\cline { 2 - 5 } & $\mathbf{f}$ & $\mathbf{\%}$ & $\mathbf{f}$ & $\mathbf{\%}$ \\
\hline Strok & 22 & 25 & 22 & 25 \\
Meningitis serosa & 6 & 6,8 & 7 & 8 \\
Myeloradiculopathy & 7 & 8 & 3 & 3,4 \\
Space Ocuppying Lesion & 2 & 2,3 & 3 & 3,4 \\
Status Epileptikus & 3 & 3,4 & - & - \\
Tetanus & 5 & 5,6 & 1 & 1,1 \\
Gullain Barre-Syndrome & 2 & 2,3 & - & - \\
Vertigo & 2 & 2,3 & 2 & 2,3 \\
Encephalitis & - & 0 & 1 & 1,1 \\
Jumlah & 49 & 55,7 & 39 & 44,3 \\
\hline
\end{tabular}

2013 sampai dengan tanggal 7 Juli 2013 tercantum pada tabel 1 , dibawah ini :

Dari tabel 1 menunjukkan bahwa diagnosa terbanyak ialah strok, dengan jumlah 44 responden atau setengahnya. Jumlah jenis kelamin seimbang, yakni 22 responden pria dan 22 responden wanita.

Dari tabel 2 terlihat dari rentang usia dewasa madya sekitar 40-60 tahun merupakan yang terbanyak yakni, 26 responden, untuk rentang usia dewasa lanjut sebanyak 13 responden, dan dewasa awal sebanyak lima responden. Diagnosa tertinggi ke-2, yakni Meningitis Serosa dengan jumlah 13 responden atau sebagian kecil. Jumlah jenis kelamin pria sebanyak enam responden untuk wanita sebanyak tujuh responden. Untuk rentang usia, terbanyak pada usia dewasa awal sebanyak tujuh responden dan dewasa madya sebanyak enam responden.

Diagnosa Myeloradiculopathy memiliki responden sebanyak 10 responden atau

Tabel 2 Distribusi Persentase Karekteristik Responden Berdasarkan Diagnosa, dan Usia pada Pasien Rawat Inap lantai 5 Neurologi Gedung Kemuning di RSHS periode 17 Juni 2013 sampai dengan 7 Juli 2013

\begin{tabular}{|c|c|c|c|c|c|c|}
\hline \multirow{3}{*}{ Diagnosa } & \multicolumn{4}{|c|}{ Usia } & \multirow{3}{*}{ f } & \multirow{3}{*}{$\%$} \\
\hline & & $\begin{array}{c}\text { Dewasa } \\
\text { Awal }\end{array}$ & $\begin{array}{l}\text { Dewasa } \\
\text { Madya }\end{array}$ & Dewasa Lanjut & & \\
\hline & $\begin{array}{c}\leq 18 \\
\text { tahun }\end{array}$ & $\begin{array}{l}18-40 \\
\text { tahun }\end{array}$ & $\begin{array}{l}40-60 \\
\text { tahun }\end{array}$ & $\begin{array}{l}60 \text { tahun } s / d \\
\text { kematian }\end{array}$ & & \\
\hline Strok & - & 5 & 26 & 13 & 44 & 50 \\
\hline Meningitis serosa & - & 7 & 6 & - & 13 & 14,8 \\
\hline Myeloradiculopathy & - & 1 & 8 & 1 & 10 & 11,4 \\
\hline Space Ocuppying Lesion & 1 & 1 & 2 & 1 & 5 & 5,7 \\
\hline Status Epileptikus & 1 & 2 & - & - & 3 & 3,4 \\
\hline Tetanus & - & 2 & 4 & - & 6 & 6,8 \\
\hline Gullain Barre-Syndrome & 2 & - & - & - & 2 & 2,3 \\
\hline Vertigo & - & - & 3 & 1 & 4 & 4,5 \\
\hline Encephalitis & - & 1 & - & - & 1 & 1,1 \\
\hline
\end{tabular}


Okatiranti: Gambaran Risiko Terjadinya Dekubitus berdasarkan Tingkat Ketergantungan Pasien

Tabel 3 Distribusi Persentase Risiko Terjadinya Dekubitus Berdasarkan Tingkat Ketergantungan Pasien di Ruang Rawat Inap Lantai 5 Neurologi Gedung Kemuning di RSHS Periode 17 Juni 2013 sampai dengan 7 Juli 2013

\begin{tabular}{|c|c|c|c|c|c|c|c|c|c|c|c|c|}
\hline \multirow{3}{*}{$\begin{array}{c}\text { Tingkat } \\
\text { Ketergan- } \\
\text { tuangan Pasien }\end{array}$} & \multicolumn{10}{|c|}{$\begin{array}{c}\text { Pengkajian Risiko Terjadinya Dekubitus dengan Menggunakan Skala } \\
\text { Barden }\end{array}$} & & \multirow{3}{*}{ f } \\
\hline & \multicolumn{2}{|c|}{$\begin{array}{c}\text { Tidak } \\
\text { Berisiko } \\
\end{array}$} & \multicolumn{2}{|c|}{ Berisiko } & \multicolumn{2}{|c|}{$\begin{array}{c}\text { Risiko } \\
\text { Sedang }\end{array}$} & \multicolumn{2}{|c|}{$\begin{array}{l}\text { Risiko } \\
\text { Tinggi } \\
\end{array}$} & \multicolumn{2}{|c|}{$\begin{array}{c}\text { Risiko Sangat } \\
\text { Tinggi }\end{array}$} & & \\
\hline & f & $\%$ & f & $\%$ & f & $\%$ & f & $\%$ & f & $\%$ & & \\
\hline Minimal Care & 15 & 17 & 2 & 2,3 & - & - & - & - & - & - & 17 & 19,3 \\
\hline Partial care & 11 & 12,5 & 17 & 19,3 & 8 & 9,1 & 1 & 1.1 & - & - & 37 & 42,0 \\
\hline Total Care & - & - & - & - & 13 & 14,8 & 15 & 17,1 & 6 & 6,8 & 34 & 38,7 \\
\hline
\end{tabular}

sebagian kecil, dengan jumlah jenis kelamin terbanyak adalah pria, dengan tujuh responden dan wanita sebanyak tiga responden. Rentang usia tertinggi pada dewasa madya, antara 40 60 tahun sebanyak delapan responden, untuk rentang usia dewasa awal dan dewasa lanjut masing-masing berjumlah satu responden. Responden terbanyak selanjutnya adalah dengan diagnosa tetanus, dengan jumlah enam responden atau sebagian kecil yang terdiri dari lima responden pria dan satu responden wanita. Rentang usia dewasa madya yang terbanyak yakni empat responden dan dewasa awal sebanyak dua responden.

Diagnosa space ocuppying lesion (SOL) memiliki lima responden atau sebagian kecil. Jenis kelamin pria sebanyak dua responden dan untuk wanita sebanyak tiga responden. Pada rentang usia, remaja sebanyak satu responden, dewasa awal satu responden, dewasa madya sebanyak dua responden dan dewasa lanjut sebanyak satu responden. Diagnosa vertigo memiliki empat responden atau sebagian kecil dengan jenis kelamin pria dan wanita seimbang yakni dua reponden. Rentang usia dewasa madya sebanyak tiga responden dan dewasa lanjut sebanyak satu responden.

Diagnosa status epileptikus memiliki tiga responden atau sebagian kecil dengan jenis kelamin seluruhnya pria dan untuk rentang usia remaja sebanyak satu responden dan dewasa awal sebanyak satu responden. Untuk diagnosa gullain barre-syndrome (GBS) memiliki dua responden atau sebagian kecil dengan jenis kelamin yang sama, yakni pria dan pada rentang usia remaja. Selanjutnya, diagnosa encephalitis dengan satu responden atau sebagian kecil dengan jenis kelamin wanita dan pada rentang usia dewasa awal.

Dari hasil penelitian pada tabel 3, risiko terjadinya dekubitus berdasarkan tingkat ketergantungan pasien bervariasi, diantaranya dengan tingkat ketergantungan pasien minimal care sebesar 19,3\% atau sebagian kecil, dengan responden sebanyak 17 responden, yang terdiri dari 15 responden atau sebagian kecil tidak berisiko untuk terjadinya dekubitus dan dua responden atau sebagian kecil berisiko untuk terjadinya dekubitus.

Tingkat ketergantungan pasien partial care sebesar $42,0 \%$ atau hampir setengahnya dengan jumlah 37 responden memiliki risiko dekubitus yang bervariasi, dari 37 responden tersebut terdapat 11 responden atau sebagian kecil yang tidak berisiko untuk terjadinya dekubitus, kemudian 17 responden atau sebagian kecil memiliki risiko untuk terjadinya dekubitus, delapan responden atau sebagian kecil memiliki risiko sedang untuk terjadinya dekubitus, dan satu responden atau sebagian kecil memiliki risiko tinggi untuk terjadinya dekubitus.

Tingkat Ketergantungan pasien total care sebesar $38,6 \%$ atau hampir setengahnya, dengan jumlah 34 responden. Dari jumlah tersebut didapatkan bahwa sebanyak 13 responden atau sebagian kecil memiliki risiko sedang untuk terjadinya dekubitus, kemudian 15 responden atau sebagian kecil memiliki risiko tinggi untuk terjadinya dekubitus dan sisanya enam responden atau sebagian kecil memiliki risiko sangat kecil untuk terjadinya dekubitus.

Dari penelitian yang telah dilakukan, didapatkan untuk hasil karekteristik responden, dengan diagnosa tertinggi ialah 
Okatiranti: Risiko Terjadinya Dekubitus berdasarkan Tingkat Ketergantungan Pasien

strok sebesar 50\% atau setengahnya, dengan jumlah 44 responden. Hasil ini sama dengan hasil studi pendahuluan sebelumnya pada tanggal 18 Maret 2013, yakni diagnosa strok ada pada peringkat pertama, dengan jumlah 13 responden dari total 35 responden. Menurut Ketua Umum Yayasan Strok Indonesia, Laksamana TNI (Pur) Sudomo (2012), dalam dasawarsa terakhir ini sesuai dengan pengamatan dan peninjauan Yayasan Strok Indonesia (Yastroki) di rumah sakit maupun yang berada dalam masyarakat, terdapat kecenderungan meningkatnya jumlah penyandang strok di Indonesia.

Dilihat dari jenis kelamin, berdasarkan hasil penelitian yang telah dilaksanakan jumlah responden antara pria dan wanita berbeda, yakni untuk pria berjumlah 49 responden atau sebagian besar dan untuk wanita berjumlah 39 responden atau hampir setengahnya. Beberapa kebiasaan dan perilaku tertentu sering dilakukan pria, yang dapat membuat kesehatan mereka berisiko seperti merokok, pola makan buruk dan mengabaikan gejala awal.

Hasil penelitian berdasarkan rentang usia, yakni usia dewasa madya dengan rentang usia antara 40-60 tahun berjumlah 49 responden merupakan yang terbanyak. Pada usia (40-60 tahun) ini terjadi proses penurunan kemampuan fisik dan psikologis (Joyce \& Hawks, 2004). Kemudian disusul oleh dewasa awal dengan jumlah 19 responden, dewasa lanjut sebanyak 16 responden dan remaja sebanyak empat responden.

Faktor-faktor yang teridentifikasi sebagai penunjang terhadap terjadinya dekubitus mencakup imobilisasi, kerusakan persepsi sensori dan atau kognisi, penurunan perfusi jaringan, penurunan status nutrisi, friksi dan daya tarikan, peningkatan kelembapan dan perubahan kulit yang berhubungan dengan usia (Smeltzer \& Bare, 2008). Adapun faktor risiko lain yang dapat menyebabkan terjadinya luka tekan, yaitu seperti indeks massa tubuh, usia, diagnosa medis, suhu tubuh, tekanan darah dan riwayat merokok (Kale, 2009). Daerah yang rentan terjadi luka meliputi sakrum dan coccygis, tuberosity ischiadicum (terutama pada orang yang duduk terlalu lama), trochanter mayor, tumit, lutut, condylus medialis tibia, caput fibulae, scapula dan siku (Smeltzer \& Bare, 2008).

\section{Pembahasan}

Dari hasil penelitian di atas, hampir sebagian besar pasien mengalami penurunan persepsi sensori, penurunan kesadaran, dan imobilisasi. Seperti pasien GBS yang mengalami kelumpuhan semua ekstremitas (quadriplegia) yang memerlukan bantuan untuk mobilisasi penuh, pasien meningitis yang mengalami penurunan kesadaran, pasien strok yang mengalami lumpuh separuh tubuh (hemiplegia), dan tak sedikit juga pasien yang mengalami kelumpuhan dari bagian pinggang ke bagian ekstremitas bawah sehingga sulit untuk melakukan pergerakan.

Gaya mekanis mendukung terjadinya luka dekubitus terutama bagi pasien dengan penurunan mobilisasi dan penurunan kesadaran, melalui terjadinya gerakan 'merosot' di tempat tidur atau ketika pasien dipindahkan atau diposisikan secara tidak tepat (misalnya, menarik pasien ke atas ke arah bagian kepala tempat tidur). Otot yang spastik dan paralisis meningkatkan kerentanan pasien terhadap luka dekubitus yang berhubungan dengan friksi dan gaya tarikan (Brunner \& Suddart, 2008). Sesuai dengan pendapat Corwin (2012), yang mengatakan bahwa ulkus dekubitus dapat dijumpai pada orang-orang yang dirawat di tempat tidur atau mengalami penurunan mobilisasi.

Hasil penelitian risiko terjadinya dekubitus berdasarkan tingkat ketergantungan pasien bervariasi, tingkat ketergantungan pasien minimal care memiliki persentase sebesar 19,3\% dengan 17 responden, yang masingmasing yakni 15 responden atau sebagian kecil tidak berisiko terjadinya dekubitus dan 2 responden atau sebagian kecil berisiko untuk terjadinya dekubitus. Hal ini didukung oleh teori Orem dalam Taylor \& Renpenning (2011), bahwa setelah dilakukan pembelajaran, bantuan yang diberikan pada pasien adalah dukungan pendidikan dengan harapan pasien mampu melakukan perawatan secara mandiri (supportive dan educative).

Tingkat ketergantungan pasien partial care, yakni sebesar $42 \%$ atau hampir setengahnya, yang terdiri dari 11 responden atau sebagian kecil tidak berisiko terjadinya dekubitus, 17 responden atau sebagian kecil berisiko terjadinya dekubitus, delapan 
Okatiranti: Risiko Terjadinya Dekubitus berdasarkan Tingkat Ketergantungan Pasien

responden atau sebagian kecil memiliki risiko sedang dan satu responden atau sebagian kecil memiliki risiko tinggi terjadinya dekubitus. Pada tingkat ketergantungan pasien partial care ini di mana perawat atau keluarga dan klien saling bekerja sama dalam melakukan tindakan keperawatan, dalam hal ini, peran perawat tidak total tetapi sebagian (Potter \& Perry, 2008).

Bantuan yang dilakukan secara penuh atau total merupakan suatu tindakan keperawatan dengan memberikan bantuan secara penuh pada pasien dikarenakan ketidakmampuan pasien dalam memenuhi tindakan perawatan secara mandiri yang memerlukan bantuan dalam pergerakan, pengontrolan, dan pergerakan serta adanya manipulasi gerakan (Basal \& Ilgas, 2010). Sesuai dengan tingkat ketergantungan pasien total care di mana persentase sebesar $38,6 \%$ atau hampir setengahnya, dengan jumlah 34 responden, di mana 13 responden atau sebagian kecil memiliki risiko sedang untuk terjadinya dekubitus, sedangkan 15 responden atau sebagian kecil memiliki risiko tinggi terjadinya dekubitus dan enam responden terakhir atau sebagian kecil memiliki risiko sangat tinggi untuk terjadinya dekubitus.

Kebutuhan perawatan diri meliputi pemeliharaan udara, air atau cairan, makanan, proses eliminasi normal, keseimbangan antara aktivitas dan istirahat, keseimbangan antara solitude (kesendirian) dan interaksi sosial, dan kesejahteraan manusia, serta upaya meningkatkan fungsi dan perkembangan individu dalam kelompok sosial sesuai dengan potensi, keterbatasan, dan keinginan untuk normal.

\section{Simpulan}

Penelitian ini merupakan penelitian kuantitatif tentang risiko terjadinya dekubitus berdasarkan tingkat ketergantungan pasien di ruang perawatan neurologi. Berdasarkan hasil penelitian dan pembahasan dapat disimpulkan bahwa responden dengan tingkat ketergantungan minimal hampir seluruhnya tidak memiliki risiko untuk terjadinya dekubitus. Responden dengan tingkat ketergantungan partial care hampir setengahnya berisiko terjadinya dekubitus dan responden dengan tingkat ketergantungan total hampir setengahnya memiliki risiko terjadinya dekubitus.

Berdasarkan hasil penelitian, diharapkan perawat dapat memperhatikan pencegahan kejadian dekubitus pada pasien di ruang perawatan neurologi, semakin tinggi tingkat ketergantungan pasien dengan pemantauan maka tindakan pencegahan harus semakin tinggi.

\section{Daftar Pustaka}

Arikunto, S. (2010). Prosedur penelitian suatu pendekatan praktik. Edisi Revisi. Jakarta: Rineka Cipta.

Bansal \& Cheryl. (2005). Decubitus ulcer: A review of the literature. International Journal Of Dermatology, 44, 805-810.

Basal, G. \& Ilgas, S. (2010). A funcional fabric for pressure ulcer prevention. Textile Research Journal, 79, 1415-1426.

Brunner \& Suddarth. (2008). Textbook of medical surgical nursing. Lippincot: Williams \& Wilkins.

Corwin, E. J. (2012). Buku saku patofisiologi (Edisi ke-3). Jakarta: EGC.

Ignatavicius, D. \& Linda, W. (2002). Medical surgical nursing, critical thingking for colaborative care. (4th ed.). New York: WB, Saunders Company.

Joyce, B.M. \& Hawks, J.H. (2004) . Medicalsurgical nursing evolve student learning resources for black an hawk: medicalsurgical nursing: Clinical management for positive outcomes (7th Ed.).

Kale, D. E. (2009). Efektifitas skala braden dalam memprediksi kejadian luka tekan di bangsal bedah-dalam RSU Prof. Dr. W.Z. Yohannes Kupang. (Tesis). Jakarta: Universitas Indonesia.

Potter, P. A. \& Perry., A. G. (2005). Buku ajar fundamental keperawatan: Konsep, proses, dan praktik. (Edisi Keempat). Jakarta: EGC. 
Okatiranti: Gambaran Risiko Terjadinya Dekubitus berdasarkan Tingkat Ketergantungan Pasien

Setyajati. (2001). Faktor-faktor yang memengaruhi kejadian dekubitus pada pasien tirah baring di rumah sakit dr. Moewardi Surakarta.

Smeltzer, S. C. \& Bare, B. G. (2008). Buku ajar keperawatan medikal bedah Brunner and Suddart. (Edisi Kedepalan). Jakarta: EGC.
Taylor, S.G. \& Renpenning, K. (2011). Selfcare science: nursing theory and evidencebased practise. New York: Springer Publishing Company.

Vanderwee, K., Grypdonck., Bacquer, D., \& Defloor, T. (2006). Effectiveness of turning with unequal time intervals on the incidence of pressure ulcer lesions. Journal of advance Nursing, 57, 59-68. 